\title{
SERVICE EXPORTS AND PRODUCTIVITY: EVIDENCE FROM OECD PANEL DATA
}

\section{Seymur Ağazade ${ }^{\text {iD }}$}

\begin{abstract}
This study aims to investigate the relationship between service exports and productivity in 27 OECD countries by using a panel dataset for the years 1995-2018. In the theoretical context, this relationship is basically handled by the learning-by-exporting and selfselection mechanisms. Additionally, product life cycle and technological gap theories also have implications related to the export and productivity association. In the study, after detecting the cross-sectional dependence, the stationarity characteristics of the exports and productivity series were investigated by Pesaran's (2007) panel unit root tests. The findings of Westerlund (2007) panel co-integration test indicated that there is a longrun equilibrium relationship between service exports and productivity. Common correlated effects estimators also supported this finding and showed that productivity affects exports positively in both short and long run. Finally, Dumitrescu and Hurlin's (2012) heterogeneous panel causality tests showed that there is a unidirectional causal relationship running from productivity to service exports. The findings support the predictions of product life cycle theory and technological gap theory regarding the exports and productivity linkage and indicate the validity of the self-selection mechanism for OECD countries' service exports.
\end{abstract}

Keywords: service exports, labour productivity in services, panel data, OECD countries JEL: C23, F14, F16

\section{Introduction}

There are quite consistent theoretical principles indicating the association of exports and productivity improvement. However, the relationship between exports and productivity is also a debated subject. The main objective of this study is to examine this subject on an example of the service sector, which is increasingly important in the economy. In economic theory, it has already been supposed that productivity growth boosts exports and furthermore, exports or foreign trade lead to productivity increases. All else equal,

a Alanya Alaaddin Keykubat University, Tourism Faculty, Alanya Turkey

E-mail: seymur.agazade@alanya.edu.tr 
an increase in productivity can be expected to lead to lower unit costs and this can make exports more profitable. On the other hand, an increase in exports has consequences related to productivity due to different influence mechanisms such as resource allocation, economies of scale and learning effects.

As known, conventional economic theory suggests that trade leads to improved productivity. This inference is mainly sourced from the opinion that trade can cause a more favourable allocation of resources. Absolute advantage and comparative advantage theories by Smith and Ricardo emphasize the advantages that arise from productivity increases as a consequence of trade. In addition, the Heckscher-Ohlin theorem is also based on the assumption that foreign trade in goods produced with intensive use of factors that are abundant in the country causes productivity increases.

Besides trade advantages in the form of productivity gains, as stated by Balassa (1978), exports may also generate technological improvements in response to competition. This context is taken further by the contributions of Helpman and Krugman (1985) and Grossman and Helpman (1991). Accordingly, trade may create productivity improvements through lower unit costs due to structural change in production composition or through technological spillovers.

Vernon's (1966) product life cycle theory and Posner's (1961) technological gap theory also have implications related to the export and productivity association. According to the product life cycle theory, exports of products from a developing country increase during the product maturing period. This increase can be considered a consequence of productivity growth originating from declining unit costs because of mass production or economies of scale. Similarly, the technological gap theory argues that trade originates from the technology difference between countries and suggests that comparative cost differences resulting from a technical change in one country encourage trade in the learning period adequate to imitate innovation by other countries. Kaldor (1967) also stressed trade outcomes of increased competitiveness caused by productivity improvements in the form of static and dynamic increasing returns in the manufacturing industry.

Therewithal, approaches related to the nature of the relationship between exports and productivity improvements can be described within the conceptual frameworks of learning-by-exporting and self-selection mechanisms. According to the learningby-exporting notion, export provides a mechanism for transfer of technology, knowhow, or more efficient production or management techniques in general and may also cause technological spillovers to non-exporting firms or sectors in exporting countries. The fundamental theoretical argument at the background of this interpretation is that firms which operate on international markets are more prone to utilize knowledge and technological spillovers from their international transactions, and operating on larger 
international markets provides a better basis for the emergence of economies of scale advantages and contributes to the human capital. Consequently, these factors promote the learning process and cause efficiency gains, which lead to productivity improvements (Marin, 1992; Bernard and Wagner, 1997; Clerides et al., 1998; Bernard and Jensen, 1999; Giles and Williams, 2000; Castellani, 2002).

In brief, this explanation suggests that exports cause productivity improvements or exporting makes exporters more productive. However, based on the fact that it is much more difficult to operate on international markets compared to domestic markets, it can also be argued that only companies with higher efficiency can enter and survive on international markets. This argument about the export-productivity linkage is known as the self-selection mechanism. One of the fundamental reasons for this thought is the additional costs that differ from domestic sales. These additional or extra costs, which can also be specified as the sunk costs, include costs of international distribution channel setup (including contract and negotiation expenses) and costs of adaptation or modification of products to international or foreign standards. Under competitive conditions, it is obvious that only more productive firms can incur these sunk costs of exporting (Roberts and Tybout, 1997; Clerides et al., 1998; Bernard et al., 2003; Helpman et al., 2004). In the same way, Balassa (1978) also argues that the extra costs may arise from transportation, distribution or marketing, improvement of personnel skills to manage foreign networks, or modification of production for foreign consumption, and these costs cause entry barriers that less productive firms cannot overcome. Simply, the self-selection hypothesis states that only more productive firms are able to export because there are fixed costs involved in entering international markets. In addition to entrance to international markets, the sustainability of exports in such a competitive environment constantly requires improvements to productivity indicators and needs efforts in this direction. This sustainability requires relatively more serious and costly market research compared with domestic markets. In this case, the strict competition on international markets forces productivity improvements and it is needed to improve products, processes, management and thus maintain the competitive advantage.

There is a considerable body of research on the export-productivity linkage. However, a large portion of these studies analyses the issue for manufacturing goods or for exports as a whole. Regarding services, although the service sector is of special importance for the economy, detailed research into the relationship between exports and productivity is largely neglected (Vogel, 2011; Temouri et al., 2013). For services, the relationship between exports and productivity may differ due to specific characteristics of services compared to physical goods. In terms of significance of the research subject, the main characteristics can be listed as inseparability, intangibility, heterogeneity, perishability and 
inability of storage. Love and Ganotakis (2013) stated that these attributes of services may have implications for the ease of firms entering and acquiring knowledge from export markets and hence for the learning-by-exporting benefits. The special relevance of inseparability and intangibility characteristics of services with regard to exporting was also highlighted by La et al. (2005). Furthermore, Love and Mansury (2009) argued that as unique characteristics of intangibility and inseparability of services imply the selfselection effects and that learning-by-exporting benefits may be smaller for services than for manufacturing. On the other hand, the simultaneity of service production with consumption and the necessity of a high degree of interaction with the customer may require significant productivity advantages for exports. Considering all these reasons for services, investigation of the export-productivity link may present substantially different conclusions.

However, despite the fact that the share of service sector in the economy in terms of both production and employment and the share of service exports in total exports increase rapidly, the studies focusing on the investigation of service exports and service sector productivity are limited. In addition, the studies in the literature mostly focus on a particular country and on certain service sub-sectors. The main contribution of this study is to fill this gap in the literature based on multinational empirical application of panel data from major service-exporting economies, namely OECD countries.

\section{Literature Review on Export and Productivity Linkage}

A large amount of studies has been done to identify the relationship between exports and productivity. Country, sector, and firm-level datasets have been used in the relevant literature for this purpose. Different variables such as export at current prices, real export and export intensity have been used as export indicators in the studies. For efficiency, indicators of labor productivity and total factor productivity have been taken into account. Since there are a limited number of studies investigating the productivityexport linkage in the service sector, firstly the studies focused on the economy in general or on the manufacturing industry were emphasized. One of the earliest studies focused on the subject is based on Austrian manufacturing data (Kunst and Marin, 1989). They investigated the relationship between productivity and exports using causality analysis. Although the unit root properties of the variables were not taken into account, the findings of their causality analysis indicated no causal link from exports to productivity while the null hypothesis of no causality from productivity to exports was rejected. Based on cointegration and Granger causality techniques, Marin (1992) tried to determine whether a causal link between exports and productivity exists for four developed market economies 
(USA, Japan, the UK and Germany). Like Kunst and Marin (1989), Marin (1992) also used manufacturing industry exports and labour productivity data. He concluded that exports, productivity and terms of trade are co-integrated in all the countries except the United Kingdom and found causality running from exports to productivity in all the four countries.

Yamada (1998) also used macro data to examine the export-led growth hypothesis for the USA, France, Canada, the UK, Italy and Japan by testing Granger causality. In his analysis, exports were taken into account in real terms and the productivity was measured by real GDP per total employment. Even though Yamada (1998) found some evidence supporting the causality from exports to productivity, different from Marin's (1992) findings, in most cases the causality analyses did not provide robust empirical evidence in favour of the export-led growth hypothesis. Similarly, based on country-level data, Hacker and Hatemi-J. (2003), Liao and Liu (2009), Kim et al. (2009) and Hatemi-J. and Irandoust (2001) focused on the export-productivity linkage. Hacker and Hatemi-J. (2003) investigated the effect of exports on growth and productivity for the Swedish economy through two VAR models. The findings of their analysis showed that the variables in each model are co-integrated. They also performed Granger causality tests and discovered bidirectional causality between real exports and total factor productivity. Liao and Liu (2009) examined the interaction between exports and productivity growth for eight East Asian economies (China, Hong Kong, Singapore, South Korea, Taiwan, Indonesia, Malaysia and the Philippines) in a multivariate model by applying a boundtest approach and modified Wald tests. They found a bidirectional causal relationship for Korea, Singapore, and Taiwan, and unidirectional causality running from productivity to exports for China, Hong Kong, Indonesia, Malaysia and the Philippines. Kim et al. (2009) investigated the relationship in one East Asian country, Korea. They found Granger causality from imports to total factor productivity growth and the absence of any causal relation between exports and total factor productivity growth. Their results showed that imports have a positive effect on total factor productivity growth, whereas exports do not. Using a larger dataset than Hacker and Hatemi-J. (2003), Hatemi-J. and Irandoust (2001) examined the co-integration and causal relationships between exports and two alternative measures of the rates of productivity growth for France, Germany, Italy, Sweden and the UK. They concluded that exports and productivity are causally related in the long run. In the case of labour productivity, they concluded that exports cause productivity growth in the case of France, Italy, Germany and Sweden. For the UK, causality runs in both directions. When total factor productivity is used, the estimated results reveal that the flow of causality is bidirectional in Germany, Italy and the UK. For France, it is found that the flow of causality runs from productivity growth to export growth, while in Sweden from export to productivity. 
Thangavelu and Rajaguru (2004) investigated the relationships between trade and labour productivity for the manufacturing industries of nine rapidly developing Asian economies (Hong Kong, India, Indonesia, Japan, Malaysia, the Philippines, Singapore, Taiwan and Thailand) using a vector error-correction model. Productivity was measured by labour productivity and all variables were taken into account in real terms. Their results indicated that, for most of the countries, imports affect productivity more strongly compared to exports. However, for India, Malaysia and the Philippines, export-led productivity growth was supported by the evidence. Another study investigating the issue through the manufacturing industries came from $\mathrm{Fu}$ (2005). He analysed the impact of exports on aggregate productivity growth in China by using a panel of manufacturing industries and found no evidence supporting significant productivity gains resulting from exports.

Studies using micro or firm-level data make up an important part of the literature. Among them, Sjöholm (1999) examined the effect of international trade on productivity in Indonesian manufacturing establishments. The estimates for the growth in value-added and value-added per employee equations showed that firms exporting parts of their output have higher productivity growth. Furthermore, the study indicated that the greater the share of output to exports, the higher the productivity growth, whereas imports do not affect the productivity growth in most estimations. Different from Sjöholm's (1999) conclusions, Wagner's (2002) findings provided only poor support to the productivity-export linkage. Wagner (2002) used a plant-level panel dataset and matching approach to test for causal effects of starting to export on firm size and productivity in Germany. His matching approach revealed significant positive effects on two indicators of plant performance and growth of employment and wages, whereas weaker evidence for a positive effect on labour productivity.

In a similar way, Castellani (2002), Hallward-Driemeier et al. (2002) and Aw et al. (2011) used firm-level data from manufacturing. Castellani (2002) focused on Italian manufacturing firms and estimated equations for the labour productivity growth rate on exports. The key finding of Castellani (2002) indicates that export positively affects productivity growth when measured by export intensity. Conversely, when export was measured simply by presence on export markets, it had no impact on productivity growth. Based on this finding, he argued that learning effects require the foreign involvement to be above a certain level.

Hallward-Driemeier et al. (2002) used data from five East Asian countries (Indonesia, Korea, Malaysia, the Philippines and Thailand) to explore the patterns of manufacturing productivity across the region. They argued that firms with foreign ownership and firms that export are significantly more productive and firms targeting export markets make 
decisions to raise productivity. According to their assessment, it is not simply that more productive firms self-select onto export markets; rather, firms that target export markets consistently make different decisions, and these decisions lead to increased productivity. These outcomes are also partially supported by the findings of Aw et al. (2011). Using plant-level data for the Taiwanese electronics industry, they found that investment in R\&D and export activities has a positive effect on future productivity and this, in turn, drives more plants to self-select into both activities, contributing to further productivity gains.

There are also studies trying to evaluate the relationship between export and productivity based on the findings of previous studies. For example, Wagner (2007) reviewed the findings of studies that used firm-level data to investigate the relationship between exports and productivity. According to the conclusion from his re-evaluation, exporters are more productive than non-exporters and the more productive firms self-select onto export markets. On the other hand, exports do not necessarily improve productivity. In another study, Martins and Yang (2009) conducted a meta-analysis of more than 30 papers that study the causal relationship between exporting and firm productivity. Their main result indicates that in developing countries the impact of exporting on productivity is higher than in developed countries.

As clarified above, the empirical studies have largely focused on the relationship between productivity and manufacturing export. In contrast, there are only a few studies that make an investigation into services. In addition, the studies in the literature have mostly focused on a particular country and on certain service sub-sectors or have been based on micro-level datasets. Among them, Vogel (2011), Eickelpasch and Vogel (2011), Vogel and Wagner (2013), Wagner (2014), and Schwarzer (2017) used data from the German service sector. Findings for the German business service sector from Vogel (2011) indicated that enterprises that export are more productive, even when controlled for size and industry. However, when unobserved time-invariant effects were controlled, he found no significant differences between exporters and non-exporters. Supporting self-selection onto export markets, he argued that the more 'able' enterprises are more likely to export. Similarly, Eickelpasch and Vogel (2011) also investigated the determinants of export behaviour of German business service companies. As in Vogel's (2011) estimations, the assumption regarding heterogeneity produced different results. When they controlled for unobserved time-invariant heterogeneity, the positive effects of labour productivity and human capital on export disappeared. In this case, firm size was still found to affect export positively. Wagner (2014) investigated the relationship between productivity and both exports and foreign direct investment in German service firms. His findings from different estimation methods did not support the results obtained in the existing literature such that firms with the highest productivity engage in foreign direct investments, the least 
productive firms serve the home market only and the productivity of exporting firms is in between. In another study regarding Germany, Schwarzer (2017) revisited the selfselection versus learning-by-exporting debate using a firm-level panel dataset and found significant pre-export differences in productivity between future exporters and domestic firms. However, these pre-export differences are found to be constant over time and the conscious self-selection effect was not supported by the evidence. In contrast, he found support for the learning-by-exporting hypothesis in both the manufacturing and service sectors. Nonetheless, the learning effect was more short-lived in the service sector.

Vogel and Wagner (2013) and Dilling-Hansen and Smith (2015) conducted the same models for German and Danish data, respectively, and their findings are in accordance with each other. Vogel and Wagner (2013) tested the hypothesis that specified that, in a given industry, productivity is the highest in firms that export and engage in R\&D, followed by firms that export and do not engage in R\&D and by firms that neither export nor engage in R\&D. Their estimations confirmed the expectations. Similarly, Dilling-Hansen and Smith (2015) concluded that the productivity distribution of exporters dominates the non-exporters.

Love and Mansury (2009) considered the link between exporting and productivity for a sample of firms from US business services. They also verified that more productive firms are more likely to become exporters, but productivity does not necessarily influence export. This conforms to the effect of self-selection onto exporting markets. Additionally, they found an association indicating that productivity is positively linked both to exports and to increased exposure to foreign markets. In the same way, the findings of Temouri et al. (2013) for the business service sector of France, Germany and the UK also supported self-selection of more productive firms into exporting. They performed an empirical study of business service exporters, comparing these exporters to non-exporters. Their findings indicated that exporters are more productive on average in all three countries.

The self-selection hypothesis was also confirmed by Minondo (2014), Morikawa (2015), and Lejárraga and Oberhofer (2015). Minondo (2014) analysed the relationship between export status and productivity in the service sector of Spain and found that exporters are 45 percent more productive than non-exporters. In addition, the exporters in the service sector were found to be more productive than non-exporters before starting to export. Morikawa (2015) used panel data from Japanese firms. Regarding the study problem, he concluded that the productivity of service-trading firms is higher than those of non-trading firms and goods-trading firms. By using firm-level data from France, Lejárraga and Oberhofer (2015) also provided some evidence supporting a positive effect of total factor productivity on export probability of firms. 


\section{Econometric Approach}

Panel data may exhibit significant cross-sectional dependence. This dependence may result from common factors/shocks, spatial effects, or unobserved purposes that concern the full panel. Ignorance of the presence of cross-sectional dependence in the data may cause estimation inconsistencies and invalid test statistics. Therefore, before starting the unit root examination and in estimations of related panel models, it is essential to examine the cross-sectional dependence. If substantial cross-sectional dependence exists, then using the conventional unit root test and estimating panel models without considering cross-sectional dependence may result in biases. In this case, it is necessary to apply the unit root test and estimation approaches that consider this problem. There are different tests for examining cross-sectional dependence. Taking into account the time and cross-section dimensions of the dataset, this study applied the CD test statistic proposed by Pesaran (2004) based on the Lagrange multiplier of Breusch and Pagan (1980):

$$
C D=\sqrt{\frac{2 T}{N(N-1)}}\left(\sum_{i=1}^{N-1} \sum_{j=i+1}^{N} \hat{\rho}_{i j}\right) .
$$

Here, $\hat{\rho}_{i j}$ is the estimated coefficient of the pairwise correlation of the error terms, $N$ is the number of cross-sections in the panel, and $T$ is the number of observations. The null hypothesis in the test is no cross-sectional dependence and can be stated as $H_{0}: \rho_{i j}=0$. Under the null hypothesis of no cross-sectional dependence, $\mathrm{CD} \rightarrow^{d} N(0,1)$ for $N \rightarrow \infty$ and $T$ is sufficiently large.

For the determination of appropriate estimation procedure for panel variables, as in time series, the stationary characteristics of the variables needs to be identified. This study uses Pesaran's (2007) unit root test, which also models cross-sectional dependence between panel units. If panel units show cross-sectional dependence, the conventional panel unit root tests may lead to misleading findings. Pesaran's (2007) test is also known as the cross-sectional augmented Dickey and Fuller (CADF) test. In the base model of the test, the correlation between panel units is modelled with lagged cross-sectional averages. If there is an autocorrelation problem in the error terms or in the factor structure of the lagged cross-sectional average, the lags of the dependent variable and the lagged differences of the cross-sectional averages are added to the basic model. Pesaran's (2007) cross-sectional augmented panel unit root test is formulated below:

$$
\Delta y_{i t}=a_{i}+b_{i} y_{i, t-1}+c_{i} \bar{y}_{t-1}+\sum_{j=0}^{p} d_{i j} \Delta \bar{y}_{t-j}+\sum_{j=1}^{p} \delta_{i j} \Delta y_{i, t-j}+e_{i t} .
$$


Here, $\bar{y}_{t-1}=\frac{1}{N} \sum_{i=1}^{N} y_{i, t-1}, \Delta \bar{y}_{t-1}=\frac{1}{N} \sum_{i=1}^{N} \Delta y_{i, t} . N$ and $T$ represent the cross-sectional and time dimensions of the panel, respectively. The result of the stationary test can be determined according to the augmented Dickey and Fuller t statistic of the $b_{\mathrm{i}}$ coefficients calculated for each cross section in the panel. The statistics proposed by Pesaran (2007) is computed as the mean of these $t$ statistics, i.e., CIPS $=\frac{1}{N} \sum_{i=1}^{N} C A D F_{i}$. The null and alternative hypotheses of the test can be expressed as $H_{0}: b_{i}=0$ and $H_{1}: b_{i}<0 i=1,2, \ldots, N_{1} ; b_{i}=0 i=N_{1}+1, N_{1}+2, \ldots, N$. Here, the null hypothesis states that the data for each cross-section contains a unit root, and the alternative hypothesis expresses that the data for at least one cross-section do not contain a unit root.

In order to investigate the long-run relationship between the service exports and labour productivity variables, this study applied the panel co-integration procedure proposed by Westerlund (2007). This test is based on error correction and does not impose any common factor restriction. In the presence of cross-sectional dependence, this problem is handled by employing the bootstrap approach to the critical values of the test statistics. To test the co-integration relationship between variables, Westerlund (2007) constructed four different tests. These four tests are essentially based on examining the existence of co-integration by determining whether each unit has its own error correction parameter. On the basis of the question addressed in this paper, to determine the relationship among $y$ and $x$, the error correction model can be presented as follows:

$$
\Delta y_{i, t}=\delta_{i}^{\prime} d_{t}+\alpha_{i}\left(y_{i, t-1}-\beta_{i} x_{i, t-1}\right)+\sum_{j=1}^{p_{i}} \varphi_{i j} \Delta y_{i, t-j}+\sum_{j=0}^{p_{i}} \gamma_{i j} \Delta x_{i, t-j}+e_{i, t} .
$$

Where $d_{t}=(1, t)$, the error correction parameter $\alpha_{i}$ determines the adjustment speed of the system to its equilibrium, which is given by $y_{i, t-1}-\beta_{i} x_{i, t-1}$, following an unexpected shock. The determination of the co-integration relationship is related to this coefficient. If the adjustment coefficient $\alpha_{i}$ is negative, this implies correction of errors, i.e., cointegration between $y_{i, t}$ and $x_{i, t}$. If $\alpha_{i}$ is equal to zero, the variables are not co-integrated. In this situation, the null hypothesis of no co-integration in the test can be represented as $H_{0}$ : $\alpha_{i}=0$. On the other hand, the alternative hypothesis varies according to the assumption regarding the homogeneity of the $\alpha_{i}$ coefficients. If the panel is heterogeneous (the $\alpha_{i}$ coefficients are not required to be equal), the alternative hypothesis can be represented as $H_{1}^{G}: \alpha_{i}<0$ for at least one $i$. In this case, the pairs of group mean test statistics given below examine the alternative hypothesis that for at least one of the panel units the variables are co-integrated: 


$$
\begin{aligned}
& G_{\tau}=\frac{1}{N} \sum_{i=1}^{N} \frac{\hat{\alpha}_{i}}{S E\left(\hat{\alpha}_{i}\right)} \\
& G_{\alpha}=\frac{1}{N} \sum_{i=1}^{N} \frac{T \hat{\alpha}_{i}}{\hat{\alpha}_{i}} .
\end{aligned}
$$

If the panel is homogenous (the $\alpha_{i}$ coefficients are equal for all $i$ ), the alternative hypothesis takes the form of $H_{1}{ }^{P}: \alpha_{i}<0$ for all $i$. In this case, the pairs of panel statistics presented below examine the alternative hypothesis that the variables are co-integrated for the entire panel:

$$
\begin{aligned}
& P_{\tau}=\frac{\hat{\alpha}}{S E(\hat{\alpha})} \\
& P_{\alpha}=T \hat{\alpha} .
\end{aligned}
$$

In order to identify the long-run coefficients, Pesaran's (2006) common correlated effects (CCE) estimators were used in this study. This technique uses cross-sectional demeaned variables and provides robust findings in the existence of cross-sectional dependence and heterogeneity problems. Furthermore, Baltagi et al. (2019) showed that the CCE estimators are valid even in the presence of endogeneity and structural changes. After examining the long-run relationship, to determine the direction of causality between export and labour productivity, the heterogeneous panel causality test developed by Dumitrescu and Hurlin (2012) was employed. As known, the traditional causality test proposed by Granger (1969) is used in order to determine whether adding lagged values of another variable to an autoregressive model can increase the forecasting ability of the model. Dumitrescu and Hurlin's (2012) approach is also known as the heterogeneous panel causality test. To test the homogeneity of the cross-sectional parameters in CCE and Dumitrescu and Hurlin's (2012) panel VAR models, this study uses Swamy's (1970) homogeneity test. Swamy's (1970) test indicated non-homogeneity of parameters of the countries in both analyses. Heterogeneous panel causality models are the forms of correction parameters added to the models of conventional Granger (1969) test, taking into account the heterogeneity of panel units. One of the PVAR models of Dumitrescu and Hurlin's (2012) heterogeneous panel causality test may be considered as follows:

$$
y_{i t}=\alpha_{i}+\sum_{k=1}^{K} \gamma_{i}^{(k)} y_{i, t-k}+\sum_{k=1}^{K} \beta_{i}^{(k)} x_{i, t-k}+\varepsilon_{i t},
$$

where $x$ and $y$ represent the stationary variables under consideration. $k$ denotes the lag length. $\gamma_{i}^{(k)}$ and $\beta_{i}^{(k)}$ are the autoregressive and the slope parameters, respectively. These parameters can be varied for each $i$ unit in the panel. $\alpha_{i}$ are the fixed individual effects. Lag lengths $K$ are the same for all cross-sections in the panel. The homogenous non- 
causality of the null hypothesis and the alternative hypothesis are defined as $H_{0}: \beta_{i}=0$ $\forall i=1, \ldots, N$ and $H_{1}: \beta_{i}=0 \forall i=1, \ldots, N_{1} ; \beta_{i} \neq 0 \forall i=N_{1}+1, N_{1}+2, \ldots, N$. The statistics proposed by Dumitrescu and Hurlin (2012) to test the causality relationship are based on the average of the Wald statistics $\left(W_{i, t}\right)$ calculated for the cross-sections in the panel, and can be expressed as follows:

$$
W_{N, T}^{H n c}=\frac{1}{N} \sum_{i=1}^{N} W_{i, t} .
$$

Under the null hypothesis of non-causality, each individual $W_{i, t}$ statistic converges to a chi-squared with $K$ degrees of freedom. The average statistic $W_{N, T}^{H n c}$ has an asymptotic distribution under the null hypothesis of non-causality. For $T, N \rightarrow \infty$ and for the fixed $T$ sample, the standardised test statistics are as follows, respectively:

$$
\begin{aligned}
Z_{N, T}^{H n c} & =\sqrt{\frac{N}{2 K}}\left(W_{N, T}^{H n c}-K\right) \rightarrow N(0,1) \\
Z_{N}^{H n c} & =\sqrt{\frac{N}{2 K} x \frac{(T-2 K-5}{T-K-} x\left[\left(\frac{T-2 K-3}{T+K-2}\right) W_{N, T}^{H n c}-K\right] \rightarrow N(0,1) .}
\end{aligned}
$$

\section{Dataset and Variables}

This study uses annual data belonging to 27 OECD countries, namely Australia, Chile, Colombia, the Czech Republic, Denmark, Estonia, Finland, France, Germany, Hungary, Israel, Italy, Korea, Latvia, Lithuania, Mexico, the Netherlands, Norway, Poland, Portugal, Slovakia, Slovenia, Spain, Sweden, Switzerland, Turkey and the United Kingdom. Since data from other OECD countries for the entire research period (1995-2018) could not be obtained and some of the techniques applied required strongly balanced data, the empirical evidence was limited to the aforementioned countries. In this study, the labour productivity is measured by the service value added per worker in constant prices (2010 US\$). In order to express the service exports in real terms, this study calculates a service price index by dividing the service value added in current prices (US\$) by the service value added in constant prices (2010 US\$) and dividing service exports in current prices (US\$) by the calculated service price index.

Here, it is thought that a discussion of the variables used in this study would be beneficial. Both directly used labour productivity and calculated service exports are variables that are transformed into real terms using relevant price indices. In the economic analysis, there are different pros and cons of these kinds of calculated variables. First of all, the use of price indices in the calculations of real variables neglects the price level differences between countries. This leads to the variables calculated in real terms 
for countries with high price levels being high, whereas they are low for countries with low price levels. However, this method makes it possible to purge the effects of price changes over time and allows identification of the common tendencies arising from price changes among nominal variables and therefore the possible relations caused by these tendencies. Beyond that, the common use of labour productivity as an efficiency indicator is basically because labour is relatively easily measurable compared to other production factors. However, in expansion and contraction periods of the business cycle, changes in employment may follow production with a delay due to the tendency of firms to avoid bearing costs such as hiring and firing (or vice versa). Naturally, in these periods, this is reflected in the indicators calculated as labour productivity per employed person in the form of significant gains and losses. Therefore, considering long-term trends rather than short-term fluctuations in labour productivity, and long-interval data rather than short-interval data, may lead to avoiding misinterpretations and minimise the inaccuracy of the estimation results. Furthermore, to obtain the real values regarding service exports, this study uses the countries' overall service price indices. Export price indices are not calculated separately for services, and it is thought that obtaining real service exports using the export price index, which also includes tangible goods, may cause more misleading results. This can be considered a more reasonable assumption, if taking into account that the exported services are also included in the overall service price index baskets, and the tendency in their prices to act together is probably higher compared to the price comovement of the service exports and total exports, which also include tangible goods.

Table 1: Basic statistics of variables and correlation

\begin{tabular}{l|c|c}
\hline & export & productivity \\
\hline Mean & 24.082 & 10.801 \\
\hline Median & 24.165 & 10.839 \\
\hline Maximum & 26.749 & 11.781 \\
\hline Minimum & 21.054 & 9.297 \\
\hline Std.dev. & 1.273 & 0.623 \\
\hline Skewness & -0.084 & -0.373 \\
\hline Kurtosis & 2.154 & 2.092 \\
\hline Jarque-Bera & $20.101^{*}$ & $37.298^{*}$ \\
\hline Observations & & 648 \\
\hline Correlation & & $0.717^{*}$ \\
\hline
\end{tabular}

Notes: ${ }^{*}$ indicate the statistical significance of the test statistic at the $1 \%$ significance level.

Source: author's calculation 
The source of our data is the World Development Indicators database and services include wholesale and retail trade and restaurants and hotels; transport, storage and communications; financing, insurance, real estate and business services; and community, social and personal services. In the analysis, the natural logarithms of both variables were used. The variables export and productivity represent the logarithmic values of real service exports and labour productivity, respectively. The basic statistics of the variables and the coefficient measuring correlation between them are given in Table 1.

\section{Empirical Results}

Before estimating the service export and labour productivity linkage, in order to test the cross-sectional dependence in data, this study applied Pesaran's (2004) CD test. As expressed in the econometric approach section, to ignore the cross-sectional dependence may cause estimation inconsistencies and invalid findings and therefore, in the presence of cross-sectional dependence, methods modelling this should be considered. According to the results presented in Table 2, it is confirmed that for both variables CD test statistics strongly reject the null hypothesis of no cross-sectional dependence across the panel units. The average correlation coefficients are also given in the table. Accordingly, in the sample of 27 OECD countries, the average correlation coefficients are found to be 0.757 and 0.578 for export and productivity, respectively. The CD statistics and correlation coefficients support the presence of cross-sectional dependence for both variables.

Table 2: Pesaran's (2004) cross-sectional dependence test results

\begin{tabular}{l|c|c}
\hline & CD statistics & Average correlation \\
\hline export & $69.50^{*}$ & 0.757 \\
\hline productivity & $53.01^{*}$ & 0.578 \\
\hline
\end{tabular}

Notes: ${ }^{*}$ indicate the statistical significance of the test statistic at the $1 \%$ significance level.

Source: author's calculation

As the CD statistics indicated the existence of cross-sectional dependence, instead of conventional panel unit root tests, this study applied the panel unit root test proposed by Pesaran (2007) to determine the stationary characteristics of the series. As known, stationarity simply implies that the statistical properties of a process do not change over time. Stationarity characteristics are important in determining the appropriate approaches to examine relationships between variables. Pesaran's (2007) panel unit root test was used for this purpose and as mentioned above, this test models cross-sectional 
dependence by lagged cross-sectional averages and lagged differences of cross-sectional averages. The CIPS statistics of Pesaran's (2007) test are shown in the Table 3. According to the estimated CIPS statistic of export and productivity, the null hypothesis of unit root cannot be rejected in both constant and trend models. On the other hand, the CIPS statistics for the first difference of both variables ( $\Delta$ export and $\Delta$ productivity) are significant at the $1 \%$ level. Hence, the CIPS test statistics support that both variables are $I(1)$.

Table 3: Pesaran's (2007) panel unit root test results

\begin{tabular}{l|c|c}
\hline & Constant & Trend \\
\hline export & -2.031 & -1.986 \\
\hline productivity & -2.038 & -2.536 \\
\hline Dexport & $-3.855^{*}$ & $-4.652^{*}$ \\
\hline Dproductivity & $-4.648^{*}$ & $-4.759^{*}$ \\
\hline
\end{tabular}

Notes: * indicate the statistical significance of the test statistic at the $1 \%$ significance level. Source: author's calculation

The unit root test findings, which indicate that both variables are stationary in the first difference, allow investigation of the long-run level relationships between export and productivity. For this purpose, in the next step, considering Pesaran's (2004) CD test statistic indicating cross-sectional dependence in the co-integration model, this study applied Westerlund's (2007) robust panel co-integration test. Westerlund's (2007) test error correction model has a different specification related to the deterministic components (constant and trend) of the model. This study performs co-integration test with a model containing a constant and a trend. The results of Westerlund's (2007) panel co-integration test are shown in Table 4. Regarding all the four test statistics, the null hypothesis of no co-integration is rejected at the $1 \%$ significance level. According to these findings, it can be said that there is a strong long-run relationship between export and productivity.

Table 4: Westerlund's (2007) panel co-integration test results

\begin{tabular}{l|c|c|c|c}
\hline Statistic & Value & Z-value & P-value & Robust P-value \\
\hline $\boldsymbol{G}_{\boldsymbol{\tau}}$ & -3.251 & -5.792 & 0.000 & 0.000 \\
\hline $\boldsymbol{G}_{\boldsymbol{\alpha}}$ & -18.724 & -5.332 & 0.000 & 0.000 \\
\hline $\boldsymbol{P}_{\boldsymbol{\tau}}$ & -13.700 & -3.170 & 0.001 & 0.000 \\
\hline $\boldsymbol{P}_{\boldsymbol{\alpha}}$ & -12.432 & -3.026 & 0.001 & 0.000 \\
\hline
\end{tabular}

Source: author's calculation 
As the presence of a co-integration relationship between the variables was observed, Pesaran's (2006) CCE technique was applied to identify the long-run coefficients. This technique uses cross-sectional demeaned variables and provides robust findings in the existence of cross-sectional dependence and heterogeneity problems. For the predicted CCE model, it was seen that the CD statistic was equal to -1.28 and statistically insignificant, revealing the correction of the cross-sectional correlation. The CCE estimators regarding the whole panel are reported in Table 5. The error correction term (export $(-1)$ ) is -0.660 and statistically significant. This finding confirms the co-integration relationship and implies that approximately $66 \%$ of any deviation returns to its long-run equilibrium in one year, and the system reaches equilibrium in approximately 1.5 years. Regarding the long-run coefficient of the lagged labour productivity, productivity $(-1)$ is positive (1.861) and statistically significant at the $5 \%$ level. In the short run, as shown in the table, the coefficient of the difference of the labour productivity ( $\Delta$ productivity) variable is also positive $(0.706)$ and significant at the $10 \%$ level. The coefficients of the labour productivity variables indicate that the elasticity is higher in the long run than in the short run.

Table 5: CCE estimation results for whole panel

\begin{tabular}{l|c|c}
\hline & Coefficient & t-statistics \\
\hline Short-run Estimators & 0.706 & $1.80^{* * *}$ \\
\hline Dproductivity & 0.699 & 1.45 \\
\hline export (-1) & 0.085 & 1.15 \\
\hline productivity (-1) & &
\end{tabular}

Long-run Estimators

\begin{tabular}{l|c|c}
\hline export (-1) & -0.660 & $-9.32^{*}$ \\
\hline productivity (-1) & 1.861 & $2.08^{* *}$ \\
\hline cons & -2.441 & -0.21 \\
\hline
\end{tabular}

Notes: ${ }^{* *}, * *$, and ${ }^{*}$ indicate the statistical significance of the test statistic at the $10 \%$, $5 \%$ and $1 \%$ significance levels.

Source: author's calculation

Regarding the short run, this study also applied a causality analysis. The causality test results are presented in Table 6. Considering Pesaran's (2004) CD test and Swamy's (1970) S-test statistics, indicating the cross-sectional dependence of panel units and heterogeneity of model parameters, in order to detect the direction of causal relationship, this study 
employed Dumitrescu and Hurlin's (2012) heterogeneous panel causality test. Regarding the test statistics for the panel as a whole, there is a unidirectional causal relationship running from $\Delta$ productivity to $\Delta$ export.

Table 6: Dumitrescu and Hurlin's (2012) panel causality test results

\begin{tabular}{|c|c|c|}
\hline & $\begin{array}{c}\text { Dependent variable: } \\
\text { (export }\end{array}$ & $\begin{array}{c}\text { Dependent variable: } \\
\Delta \text { productivity }\end{array}$ \\
\hline W-bar & 2.063 & 0.915 \\
\hline Z-bar & $3.904^{*}$ & -0.314 \\
\hline Z-bar tilde & $2.835^{*}$ & -0.610 \\
\hline
\end{tabular}

Notes: * indicate the statistical significance of the test statistic at the $1 \%$ significance level.

Source: author's calculation

Finally, the individual country estimates of the CCE and Dumitrescu and Hurlin's (2012) PVAR models were presented in Table 6. According to the CCE country-specific results, all the estimated error correction terms are negative and most of these coefficients are statistically significant. This finding supports the co-integration relationship. Furthermore, the CCE long-run estimators (the coefficients of the lagged labour productivity productivity $(-1)$ ) are statistically significant in six cases (five positives and one negative). As a final point, in the PVAR model equation estimated for the difference of the export variable, the coefficients of the lagged labour productivity differences are significant in eight cases (six positives and two negatives). 
Table 7: CCE and PVAR country-specific results

\begin{tabular}{|c|c|c|c|}
\hline & \multicolumn{2}{|c|}{ CCE } & \multirow{2}{*}{ PVAR } \\
\hline & export $(-1)$ & productivity (-1) & \\
\hline Australia & $-0.536^{* * *}$ & 4.216 & -1.080 \\
\hline Chile & $-0.831^{* *}$ & -0.326 & 0.506 \\
\hline Colombia & -0.798 & -0.516 & 0.555 \\
\hline Czech & $-0.820^{*}$ & -1.389 & -1.066 \\
\hline Denmark & $-1.004^{*}$ & $7.947^{*}$ & 2.427 \\
\hline Estonia & $-0.650^{* *}$ & -0.764 & 0.042 \\
\hline Finland & $-0.562^{*}$ & -2.044 & 2.640 \\
\hline France & -0.365 & $3.317^{* *}$ & $2.321^{* *}$ \\
\hline Germany & -0.047 & 0.385 & 0.713 \\
\hline Hungary & -0.349 & 0.462 & $-1.149^{* *}$ \\
\hline Israel & $-1.237^{*}$ & 3.171 & -0.878 \\
\hline Italy & $-0.487^{*}$ & 0.633 & 0.499 \\
\hline Korea & -0.370 & -1.006 & $4.878^{* *}$ \\
\hline Latvia & $-0.341^{* *}$ & $2.501^{*}$ & 0.403 \\
\hline Lithuania & $-0.735^{*}$ & 0.320 & -0.530 \\
\hline Mexico & $-0.385^{* * *}$ & -0.806 & -0.288 \\
\hline Netherlands & $-1.447^{*}$ & -0.001 & $1.900^{* *}$ \\
\hline Norway & $-0.589 * *$ & 0.561 & 1.972 \\
\hline Portland & -0.579 & -1.030 & $-1.596^{*}$ \\
\hline Portugal & $-0.952^{* *}$ & $1.162^{* * *}$ & 0.312 \\
\hline Slovakia & $-1.029^{*}$ & $-3.939 *$ & 0.059 \\
\hline Slovenia & $-0.270^{* * *}$ & $3.062^{* * *}$ & 0.498 \\
\hline Spain & $-0.391^{*}$ & -0.206 & -1.176 \\
\hline Sweden & $-0.555^{* *}$ & -0.976 & $2.064^{* *}$ \\
\hline Switzerland & -0.121 & 1.373 & -0.818 \\
\hline Turkey & $-1.486^{*}$ & 2.011 & $2.525^{* *}$ \\
\hline United Kingdom & $-0.885^{* * *}$ & -1.618 & $1.281 * * *$ \\
\hline
\end{tabular}

Notes: ${ }^{* * *},{ }^{* *}$, and ${ }^{*}$ indicate the statistical significance of the test statistic at the $10 \%, 5 \%$ and $1 \%$ significance levels.

Source: author's calculation 


\section{Conclusions}

Economic development and accompanying structural transformation have led to change in the centre of gravity of economies from industry to services. Accordingly, services are no longer regarded as non-tradable and international trade in services is growing in importance in the world. These conclusions may also be considered a prediction of Engel's law and if we consider this fundamental principle, it can be expected that the importance of services in world trade will continue to increase. Therefore, it is thought that the background of export performance in services deserves to be considered more in depth, including productivity growth in this sector. It is known that services have several features different from physical goods such as inseparability, intangibility, heterogeneity, perishability, and inability of storage. It can be said that these features may cause less effective international trade restrictions on services and dissimilarities in the service export and productivity linkage. Due to the increasing importance of the service sector in the economy, the determination of the nature of the relationship between service exports and productivity is also important for policy makers.

On the other hand, it is observed that studies in the empirical literature dealing with this issue in the context of the service sector are very limited and generally based on micro or sub-sector data. This study endeavours to fill this gap in the literature by analysing the relationship between real service exports and labour productivity in services in the case of OECD countries, which are important in terms of service exports. For this purpose, panel data methods were used with a dataset covering the years from 1995 to 2018.

In the analysis, the results of Pesaran's (2004) cross-sectional dependence test suggested the presence of cross-sectional dependence across countries for both variables. Considering this finding, it can be said for each variable separately that the series of individual panel units are related or affected by some other common variables. The common correlation coefficients are calculated to be 0.794 and 0.578 for service exports and labour productivity, respectively, showing that the dependencies are not weak. The findings of Pesaran's (2007) CIPS panel unit root test, which allows identification of cross-sectional dependence across panel units, proposed that both variables are stationary in their first difference. The unit root test findings that both series are not stationary at their levels indicate that the series of real export and labour productivity do not tend to return to their long-run levels after external shocks. Considering the findings of stationary analysis, the long-run relationship between service exports and labour productivity were tested using Westerlund's (2007) co-integration procedure, and the findings of this test indicated a long-run equilibrium relationship. The CCE estimators also supported the longrun relationship and indicate that approximately $66 \%$ of any deviation returns to its long- 
run equilibrium in one year for the 27-country panel. The findings of the CCE estimator regarding the country-specific individual effects showed that labour productivity affects service exports positively in Denmark, France, Latvia, Portugal and Slovenia, whereas it does so negatively in Slovakia.

Finally, Dumitrescu and Hurlin's (2012) heterogeneous panel causality test identified a unidirectional causal relationship from labour productivity to service exports. The short-run individual country-specific effects of labour productivity on service exports in the PVAR model were found to be positive for France, Korea, the Netherlands, Sweden, Turkey and the United Kingdom, and negative for Hungary and Lithuania.

The obtained results indicate that labour productivity improvement positively affects service exports in OECD countries in the short and long term. In this respect, it can be said that the findings are theoretically in line with the predictions of Vernon's (1966) product life-cycle theory and Posner's (1961) technological gap theory regarding the exportproductivity linkage. Furthermore, the results indicate the validity of the self-selection mechanism for OECD countries' service exports. In this regard, this study is similar in terms of achieving findings supporting the same argument as studies such as Love and Mansury (2009), Vogel and Wagner (2013), Dilling-Hansen and Smith (2015), Temouri et al. (2013), Lejárraga and Oberhofer (2015), Minondo (2014), and Morikawa (2015), in which service exports were handled at the firm or sector level. However, it is also seen that the individual effects of the countries covered in this study are not uniform and differ from each other. It is thought that this dissimilarity may result from the difference in the capital, labour or knowledge intensities of the service as well as the productivity level in the countries. In addition, it is thought that the findings indicating that the individual country-specific effects are negative in few cases may be due to the income level increase caused by the productivity improvement and, therefore, rapidly growing domestic service demand, which has a considerably high income elasticity.

Considering the tendency of increase in income level over a long period of time and the higher income elasticity of services, it can be estimated that, compared to tangible goods, the share of services in the economy will continue to increase. This also indicates that the share of services in total expenditures and exports will increase over time. In the light of the findings of the study, which imply that labour productivity improvement boosts service exports in the short and long term, this situation makes the labour productivity growth in the service sector more important for countries to achieve their export targets. To achieve these targets, it is thought that after basic education the vocational education and training are especially essential because of their importance in gaining certain skills. On the other hand, the increase in the share of young people not in employment, education, or training in official statistics of many countries denotes that there are important 
problems regarding the future course of labour productivity growth. Furthermore, the jobskills mismatch is another common problem on labour markets, which also hinders labour productivity growth. In this context, it is considered that in order to achieve their export targets, countries need to find solutions to these problems that weaken their labour productivity growth and to redesign or evolve their education in a way that provides required skills, ability, and competence.

\section{References}

Aw, Bee Yan, Mark J. Roberts, and Daniel Yi Xu. 2011. R\&D Investment, Exporting, and Productivity Dynamics. American Economic Review, 101: 1312-1344. http://dx.doi.org/10.1257/aer.101.4.1312

Baltagi, Badi H., Qu Feng and Chihwa Kao. 2019. Structural Changes in Heterogeneous Panels with Endogenous Regressors. Applied Economics, 34(6): 883-892. https://doi.org/10.1002/jae.2712

Bernard, Andrew B., and Joachim Wagner. 1997. Exports and Success in German Manufacturing. Weltwirtschaftliches Archiv, 133: 134-157. https://doi.org/10.1007/ BF02707680

Bernard, Andrew B., Jonathan Eaton, J. Bradford Jensen, and Samuel Kortum. 2003. Plants and Productivity in International Trade. Econometrica, 93(4): 1268-1290. http://dx.doi.org/10.1257/000282803769206296

Bernard, Andrew B., and J. Bradford Jensen. 1999. Exporting and Productivity. NBER Working Paper 7135.

Balassa, Bela. 1978. Exports and Economic Growth: Further Evidence. Journal of Development Economics, 5(2): 181-189. https://doi.org/10.1016/0304-3878(78)90006-8

Breusch, Trevor S., and Adrian R. Pagan. 1980. The Lagrange Multiplier Test and Its Applications to Model Specification in Econometrics. The Review of Economic Studies, 47(1): 239-253. https://doi.org/10.2307/2297111

Castellani, Davide. 2002. Export Behavior and Productivity Growth: Evidence from Italian Manufacturing Firms. Weltwirtschaftliches Archiv, 138(4): 605-628. https://doi.org/10.1007/BF02707654

Clerides, Sofronis K., Saul Lach, and James R. Tybout. 1998. Is Learning by Exporting Important? Micro-Dynamic Evidence from Colombia, Mexico, and Morocco. The Quarterly Journal of Economics, 113(3): 903-947. https://doi.org/10.1162/003355398555784

Dickey, David A., and Wayne A. Fuller. 1981. Likelihood Ratio Statistics for Autoregressive Time Series with A Unit Root. Econometrica, 49(4): 1057-1072. https://doi.org/10.2307/1912517 
Dilling-Hansen, Mogens, and Valdemar Smith. 2015. R\&D, Export and Productivity in Business Services Firms: Testing the Bustos Model. Applied Economics Letters, 22(16): 1309-1314. https://doi.org/10.1080/13504851.2015.1026577

Dumitrescu, Elena-Ivona, and Christophe Hurlin. 2012. Testing for Granger Non-causality in Heterogeneous Panels. Economic Modelling, 29(4): 1450-1460. https://doi. org/10.1016/j.econmod.2012.02.014

Eickelpasch, Alexander, and Alexander Vogel. 2011. Determinants of the Export Behaviour of German Business Services Companies. The Service Industries Journal, 31 (4): 513-526. https://doi.org/10.1080/02642069.2010.504304

Fu, Xiaolan. 2005. Exports, Technical Progress and Productivity Growth in a Transition Economy: A Non-parametric Approach for China. Applied Economics, 37(7): 725-739. https://doi.org/10.1080/00036840500049041

Giles, Judith A., and Cara L. Williams. 2000. Export-led Growth: A Survey of the Empirical Literature and Some Non-causality Results. Part 2. Journal of International Trade \& Economic Development, 9(4): 445-470. https://doi.org/10.1080/096381900750056867

Granger, Clive W.J. 1969. Investigating Causal Relations by Econometric Models and Cross Spectral Method. Econometrica, 37(3): 424-438. https://doi.org/10.2307/1912791

Grossman, Gene M., and Elhanan Helpman. 1991. Innovation and Growth in the Global Economy. The MIT Press, Cambridge.

Hallward-Driemeier, Mary, Giuseppe larossi, and Kenneth L. Sokoloff. 2002. Exports and Manufacturing Productivity in East Asia: A Comparative Analysis with Firm-level Data. NBER Working Paper 8894.

Hacker, R. Scott, and Abdulnasser Hatemi-J. 2003. How Productivity and Domestic Output are Related to Exports and Foreign Output in the Case of Sweden. Empirical Economics, 28: 767-782. https://doi.org/10.1007/s00181-003-0158-4

Helpman, Elhanan, and Paul R. Krugman. 1985. Market Structure and Foreign Trade: Increasing Returns, Imperfect Competition and the International Economy. The MIT Press, Cambridge.

Helpman, Elhanan, Marc J. Melitz, and Stephen R. Yeaple. 2004. Export Versus FDI with Heterogeneous Firms. American Economic Review, 94 (1): 300-316. https://doi.org/10.1257/000282804322970814

Liao, Hailin, and Xiaohui Liu. 2009. Export-total Factor Productivity Growth Nexus in East Asian Economies. Applied Economics, 41(13): 1663-1675. https://doi.org/10.1080/00036840601032193

Hatemi-J., Abdulnasser, and Manuchehr Irandoust. 2001. Productivity Performance and Export Performance: A Time-series Perspective. Eastern Economic Journal, 27(2): 149-164.

La, Vinh Q., Paul G. Patterson, and Chris W. Styles. 2005. Determinants of Export Performance across Service Types: A Conceptual Model. Journal of Services Marketing, 19(6): 379-391. https://doi.org/10.1108/08876040510620157

Lejárraga, Iza, and Harald Oberhofer. 2015. Performance of Small- and Medium-sized Enterprises in Services Trade: Evidence from French Firms. Small Business Economics, 45: 673-702. https://doi.org/10.1007/s11187-015-9647-z 
Love, James H., and Panagiotis Ganotakis. 2013. Learning by Exporting: Lessons from HighTechnology SMEs. International Business Review, 22(1): 1-17. https://doi.org/10.1016/j. ibusrev.2012.01.006

Love, James H., and Mica Ariana Mansury. 2009. Exporting and Productivity in Business Services: Evidence from the United States. International Business Review, 18: 630-642. https://doi.org/10.1016/j.ibusrev.2009.08.002

Kaldor, Nicholas. 1967. Strategic Factors in Economic Development. New York State School of Industrial and Labor Relations, Cornell University.

Kim, Sangho, Hyunjoon Lim, and Donghyun Park. 2009. Imports, Exports and Total Factor Productivity in Korea. Applied Economics, 41(14): 1819-1834. https://doi.org/10.1080/00036840601032243

Kunst, Robert M., and Dalia Marin. 1989. On Exports and Productivity: A Causal Analysis. The Review of Economics and Statistics, 71(4): 699-703. https://doi.org/10.2307/1928115

Marin, Dalia. 1992. Is the Export-led Growth Hypothesis Valid for Industrialized Countries? The Review of Economics and Statistics, 74(4): 678-688. https://doi.org/10.2307/2109382

Martins, Pedro S., and Yong Yang. 2009. The Impact of Exporting on Firm Productivity: A Meta-analysis of the Learning-by-exporting Hypothesis. Review of World Economics, 145: 431-445. https://doi.org/10.1007/s10290-009-0021-6

Minondo, Asier. 2014. The Relationship between Export Status and Productivity in Services: A Firm-level Analysis for Spain. Bulletin of Economic Research, 66: S138-S146. https://doi.org/10.1111/boer.12029

Morikawa, Masayuki. 2015. Service Trade and Productivity: Firm-level Evidence from Japan. RIETI Discussion Paper 15-E-030.

Pesaran, M. Hashem. 2004. General Diagnostic Tests for Cross Section Dependence in Panels. University of Cambridge Faculty of Economics, Cambridge WP 0435 in Economics.

Pesaran, M. Hashem. 2006. Estimation and Inference in Large Heterogeneous Panels with a Multifactor Error Structure. Econometrica, 74(4): 967-1012. https://doi.org/10.1111/j.1468-0262.2006.00692.x

Pesaran, M. Hashem. 2007. A Sample Panel Unit Root Test in the Presence of Cross Section Dependence. Journal of Applied Econometrics, 22(2): 265-312. https://doi.org/10.1002/ jae.951

Posner, Michael V. 1961. International Trade and Technical Change. Oxford Economic Papers, 13(3): 323-341. https://doi.org/10.1093/oxfordjournals.oep.a040877

Roberts, Mark J., and James R. Tybout. 1997. The Decision to Export in Colombia: An Empirical Model of Entry with Sunk Costs. The American Economic Review, 87(4): 545-564.

Schwarzer, Johannes. 2017. The Effects of Exporting on Labour Productivity: Evidence from German Firms. CEP Working Paper 2017/2

Sjöholm, Fredrik. 1999. Exports, Imports and Productivity: Results from Indonesian Establishment Data. World Development, 27(4): 705-715. https://doi.org/10.1016/ S0305-750X(98)00160-0 
Swamy, Paravastu A.V.B. 1970. Efficient Inference in A Random Coefficient Regression Model. Econometrica, 38(2): 311-323. https://doi.org/10.2307/1913012

Temouri, Yama, Alexander Vogel, and Joachim Wagner. 2013. Self-selection into Export Markets by Business Services Firms - Evidence from France, Germany and the United Kingdom. Structural Change and Economic Dynamics, 25: 146-158. https://doi.org/10.1016/j.strueco.2012.02.004

Thangavelu, Shandre Mugan, and Gulasekaran Rajaguru. 2004. Is there an Export or Importled Productivity Growth in Rapidly Developing Asian Countries? A Multivariate VAR Analysis. Applied Economics, 36(10): 1083-1093. https://doi.org/10.1080/0003684042000246795

Vernon, Raymond. 1966. International Investment and International Trade in the Product Cycle. The Quarterly Journal of Economics, 80: 190-207. https://doi.org/10.2307/1880689

Vogel, Alexander. 2011. Exporter Performance in the German Business Services Sector. The Service Industries Journal, 31(7): 1015-1031. https://doi.org/10.1080/ 02642060903079410

Vogel, Alexander, and Joachim Wagner. 2013. Exports, R\&D and Productivity in German Business Services Firms: A Test of the Bustos Model. The Empirical Economics Letters, 12: 1-6.

Wagner, Joachim. 2002. The Causal Effects of Exports on Firm Size and Labor Productivity: First Evidence from a Matching Approach. Economics Letters, 77(2) 287-292. https://doi.org/10.1016/S0165-1765(02)00131-3

Wagner, Joachim. 2007. Exports and Productivity: A Survey of the Evidence from Firm-level Data. World Economy, 30(1): 60-82. https://doi.org/10.1111/j.1467-9701.2007.00872.x

Wagner, Joachim. 2014. Exports, Foreign Direct Investments and Productivity: Are Services Firms Different? The Service Industries Journal, 34:1, 24-37. https://doi.org/10.1111/ j.1467-9701.2007.00872.x

Westerlund, Joakim. 2007. Testing for Error Correction in Panel Data. Oxford Bulletin of Economics and Statistics, 69(6): 709-748. https://doi.org/10.1111/j.1468-0084.2007.00477.x

Yamada, Hiroshi. 1998. A Note on the Causality between Export and Productivity: An Empirical Re-examination. Economics Letters, 61, 1, 1: 111-114. https://doi. org/10.1016/S0165-1765(98)00154-2 